\title{
An active Catharanthus roseus desacetoxyvindoline-4-hydroxylase-like gene and its transcriptional regulatory profile
}

\author{
Chen Zhou, Jin Zhang, Shu-Juan Zhao* and Zhi-Bi Hu*
}

\begin{abstract}
Background: Desacetoxyvindoline-4-hydroxylase is a key enzyme in the biosynthesis of vindoline, the important intermediate leading to vinblastine and vincristine in Catharanthus roseus.

Results: A d4h-like gene has been isolated from C. roseus $C_{20}$ hi cells based on an EST sequence from the Suppression Subtractive Hybridization cDNA library. The full length cDNA of $d 4$ h-like was 1427 bp encoding 372 amino acids. It had $66 \%$ identities and $80 \%$ positives with $d 4 h$ at the amino acid level. It belonged to 2-oxoglutarate dependent oxygenase superfamily as $d 4 h$ did. Real-time quantitative PCR analysis revealed that $d 4 h$-like was expressed high in roots, flowers and $\mathrm{C}_{20}$ hi cells, very low in leaves and stems. Methyl jasmonate could significantly increase the accumulation of $d 4 h$-like transcripts. 2,4-D inhibited its expression. An approximate 2,910 bp of 5'-promoter region of d4h-like was obtained, fused to GUS reporter gene and analyzed with fluorescence quantitative assays using transient expression in C. roseus cell suspensions, indicating that $d 4 h$-like promoter could drive GUS gene expression in vivo.
\end{abstract}

Conclusion: These results suggest that $d 4 h$-like is closely related with $d 4 h$ in the genetic evolution but with different transcriptional expression profiles. It may be revolved in the hormone-independency of $\mathrm{C}_{20}$ hi cells.

Keywords: Catharanthus roseus; $C_{20}$ hi cells; Desacetoxyvindoline-4-hydroxylase; d4h-like; GUS activity; Real-time quantitative PCR; Transient expression

\section{Background}

Vinblastine and vincristine are powerful anticancer compounds produced by Madagascar periwinkle (Catharanthus roseus (L.) G. Don.) and derived by the coupling of the monomeric alkaloids catharanthine and vindoline in plants (El-Sayed and Verpoorte 2007). Research revealed that vindoline was transformed from tabersonine through a sequence of six strictly ordered enzyme reactions including aromatic hydroxylation, $O$-methylation, hydration of the 2,3-double bond, $N(1)$-methylation, 4-hydroxylation, and 4-O-acetylation (El-Sayed and Verpoorte 2007). Desacetoxyvindoline-4-hydroxylase (D4H, E.C.1.14.11.11) catalyzed the 4-hydroxylation of desacetoxyvindoline to form deacetylvindoline (Vazquez-Flota et al. 1997) which consequently converted to vindoline by deacetylvindoline-

\footnotetext{
*Correspondence: zhaoshujuan@126.com; huzhibi@hotmail.com The SATCM Key Laboratory for New Resources \& Quality Evaluation of Chinese Medicines and Shanghai Key Laboratory of Complex Prescription, Institute of Traditional Chinese Material Medica, Shanghai University of Traditional Chinese Medicine, 201203 Shanghai, China
}

4-O-acetyltransferase (DAT) (Power et al. 1990). D4H was a 2-oxoglutarate-dependent dioxygenase and could be induced by light and red-light (Verpoorte et al. 2000). It was localized at cytoplasm and its mRNA were associated with the laticifer and idioblast cells of the leaves, stems and flower buds (St-Pierre et al. 1999). Hydroxylase assays and RNA-blot hybridization studies showed that D4H activity was closely related to the levels of $d 4 h$ transcripts, occurring predominantly in young leaves and in much lower levels in stems and fruits (Vazquez-Flota et al. 1997). The biosynthesis of vindoline was also light-induced and had tissue-specific accumulation profile which was coincided with the expression patterns of $d 4 h$ (El-Sayed and Verpoorte 2007).

The $\mathrm{D} 4 \mathrm{H}$ enzyme and corresponding gene were elucidated in C. roseus. Till now, there was no homologous gene of $d 4 h$ having been reported. Recently, a special C. roseus cell line $\mathrm{C}_{20}$ hi was achieved in culturing the C. roseus $\mathrm{C}_{20} \mathrm{D}$ cells by gradually reducing the hormones in the media in our lab. These cells were hormone- 
independent and could produce much more tryptamine, serpentine, and ajmalicine than the original cell line $\mathrm{C}_{20} \mathrm{D}$. Using cell lines $\mathrm{C}_{20}$ hi and $\mathrm{C}_{20} \mathrm{D}$, a Suppression Subtraction Hybridization ( $\mathrm{SSH}$ ) cDNA library was established. Interestingly, a $671 \mathrm{bp}$ fragment, containing the 3'-untranslated region, highly similar to $d 4 h$ at the amino acid level was obtained in the library. Here, we reported the isolation and characterization of the full length cDNA and the promoter regions of $d 4$-like (GenBank accession number: EF640810, GU363550).

\section{Methods}

\section{Plant and cell material}

Catharanthus roseus cells were cultured in liquid B5 basic media by adding 2,4-D (2,4-dichlorophen-oxyacetic acid) and kinetin for $\mathrm{C}_{20}, 2,4-\mathrm{D}$ for $\mathrm{C}_{20} \mathrm{D}$, and without any hormone for $\mathrm{C}_{20}$ hi with shaking at $100 \mathrm{rpm}$ in a shaker at $25^{\circ} \mathrm{C}$ under dark. C. roseus plant was cultivated in the growth chamber at $25^{\circ} \mathrm{C}$ with a photoperiod of $16 \mathrm{~h}$ light and $8 \mathrm{~h}$ dark.

\section{RNA isolation}

Total RNAs were isolated using RNA Extraction Kit (Takara Biotechnology, Dalian, China) from different tissues and cells of $C$. roseus and checked with agarose gel electrophoresis and spectrophotometer (HITACHI U-2900) analysis. RNA samples were stored at $-80^{\circ} \mathrm{C}$ before use.

\section{Cloning of the full length CDNA, genomic DNA and promoter region of $d 4 h$-like}

The 5'-RACE was performed using SMART RACE cDNA Amplification Kit (Clontech). Gene-specific primers were
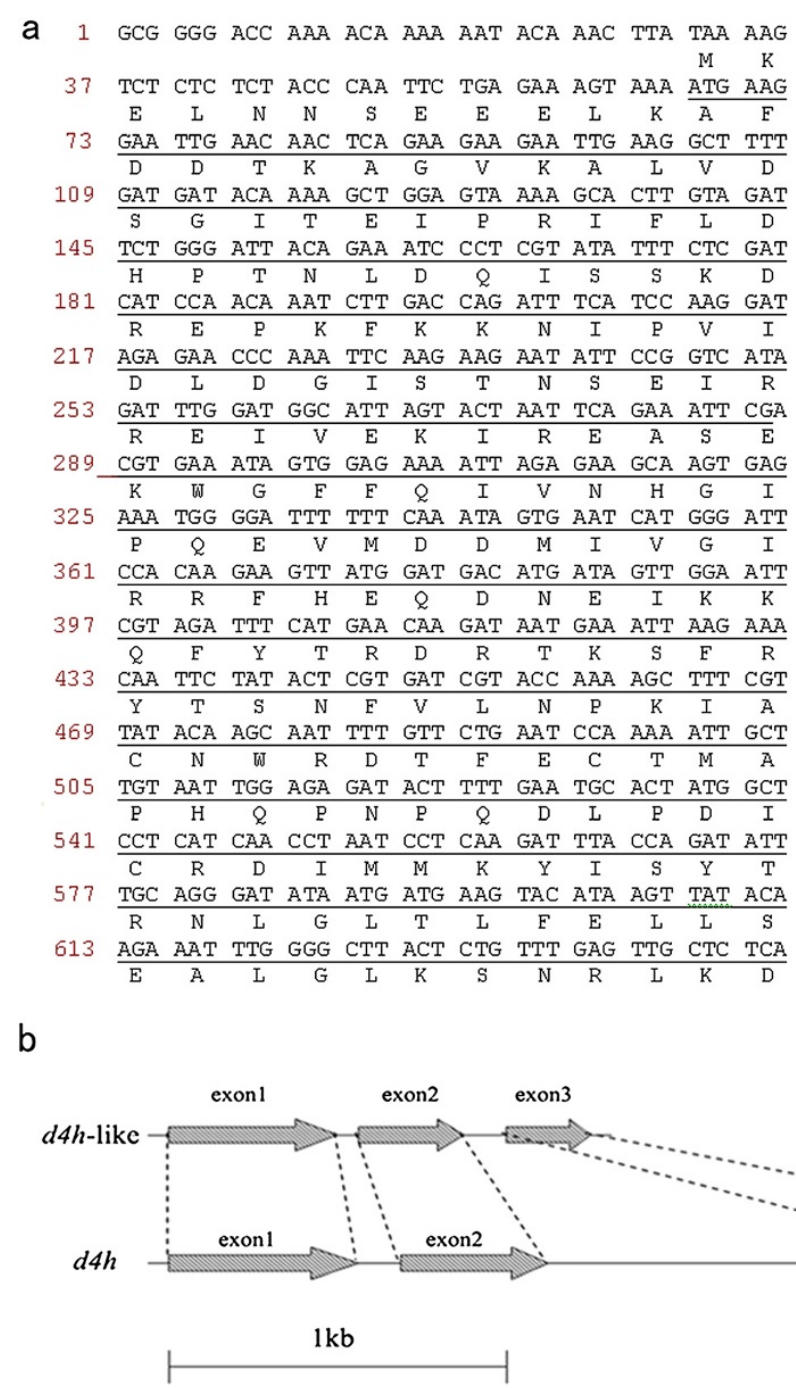

Figure 1 cDNA sequence and genomic structute of $d 4 h$-like a) Nucleotide sequence of $d 4 h$-like cDNA and the predicted amino acid residues. The open reading frame was underlined. Corresponding amino acid residues were above the nucleotide sequence. Putative polyadenylation signal was in box and the polyA tail was highlighted with shadow. b) Genomic organization of $d 4 h-l i k e$ and $d 4 h$. 
designed based on the 671 bp of EST sequence of $d 4$ h-like from SSH cDNA library. Universal Primer A Mix (UPM) coupled with $5^{\prime}$ nested universal primer (NUP) were used to do the PCR amplification according to the direction. PCR products were recovered from 1\% agarose gel, inserted into pMD18-T vector (Takara), and sequenced. Full length cDNA of $d 4 h$-like was amplified using genespecific primers D4HL-F and D4HL-R.

GenomeWalker ${ }^{\mathrm{TM}}$ Universal Kit (Clontech) was used to isolate the $5^{\prime}$ - upstream sequence of d4h-like. DNA was isolated with DNA Extraction Kit (Takara) from $C$. roseus leave. Genomic DNA of d4h-like was cloned using gene-specific primers. To get the 5 '-promoter region, DNA was digested with restriction enzymes DraI, EcoRV, $P v u$ II, and Stu I, purified and ligated with GenomeWalker Adaptor, separately. Primary and secondary PCR were consequentially carried out. PCR products were ligated into T-vector and sequenced as described above. All the primers used in this research were listed in Additional file 1: Table S1.

\section{Sequence analysis}

Sequence analysis and multiple alignments were conducted using Vector NTI 7.1 (InforMax, USA). Putative cis-regulatory elements of the promoter region were predicted with PlantCARE online software. Phylogenetic tree was established applying MegAlign with CLUSTAL W method.

\section{Protein expression in Escherichia coli}

Open reading frame fragment of $d 4 h$-like cDNA amplified with high-fidelity Taq DNA polymerase (TaKaRa) was fused into the pRSET (Invitrogen) vector and confirmed by sequencing. The vector was transferred into $E$. coli strain BL21 (DE3) to express the proteins according to the direction for pRSET kit. Water-soluble recombinant proteins were separated with SDS-PAGE electrophoresis.

\section{Real-time quantitative PCR and semi-quantitative RT-PCR analysis}

About $2 \mu \mathrm{g}$ of total RNA was used as template to perform reverse transcription with PrimeScript RT Reagent Kit (TaKaRa). Real-time quantitative PCR (qPCR) was carried out on an ABI StepOnePlus PCR System (Applied Biosystems) using the SYBR premix ExTaq polymerase following thermal cycling conditions recommended by the manufacturer. RSP9 was used as internal reference gene (Peebles et al. 2009). Each sample was repeated at least three times. Data were analyzed with StepOne software V2.1.

The semi-quantitative RT-PCR was performed with $\beta$-actin as the reference control. The PCR program was as followed: $94^{\circ} \mathrm{C}$ for $2 \mathrm{~min}$, followed by 32 cycles (for $d 4 h$-like gene) or 28 cycles (for $\beta$-actin gene) at $94^{\circ} \mathrm{C}$ for $15 \mathrm{~s}, 53^{\circ} \mathrm{C}$ for $20 \mathrm{~s}$ and $72^{\circ} \mathrm{C}$ for $60 \mathrm{~s}$, and then a final extension at $72^{\circ} \mathrm{C}$ for $5 \mathrm{~min}$. PCR products were separated on $1 \%$ agarose gels stained with ethidium bromide (10 mg/mL).

\section{Construction of promoter-GUS fusions}

A modified pCaMV35S: GUS vector was created by replacing GFP in pCAMBIA1302 (http://www.cambia.org) with a GUS gene. Promoter: GUS vectors were generated by replacing the CaMV35S promoter cassette with promoter fragments, $-1845 /+140 \mathrm{bp},-1167 /+140 \mathrm{bp}$, and $-483 /+140 \mathrm{bp}$, respectively. Each fusion was verified with DNA-sequencing. Plasmid was introduced into $A$. tumefaciens GV3101 through triparental mating using Escheridhia coli harboring pRK 2013 as conjugal helper strain.

\section{Agrobacterium-mediated transient expression}

Transient expression was performed according to Wang et al. (2010). Briefly, individual colony of transformed $A$. tumefaciens was picked and cultured to a final $\mathrm{OD}_{600}$ of 0.6 in Luria-Bertani liquid media containing kanamycin (100 mg/L) and rifampicin (100 mg/L). A. tumefaciens pellets were collected, washed and added into flasks containing $20 \mathrm{~mL}$ of fresh $C$. roseus $\mathrm{C}_{20}$ hi cells and $100 \mu \mathrm{M}$

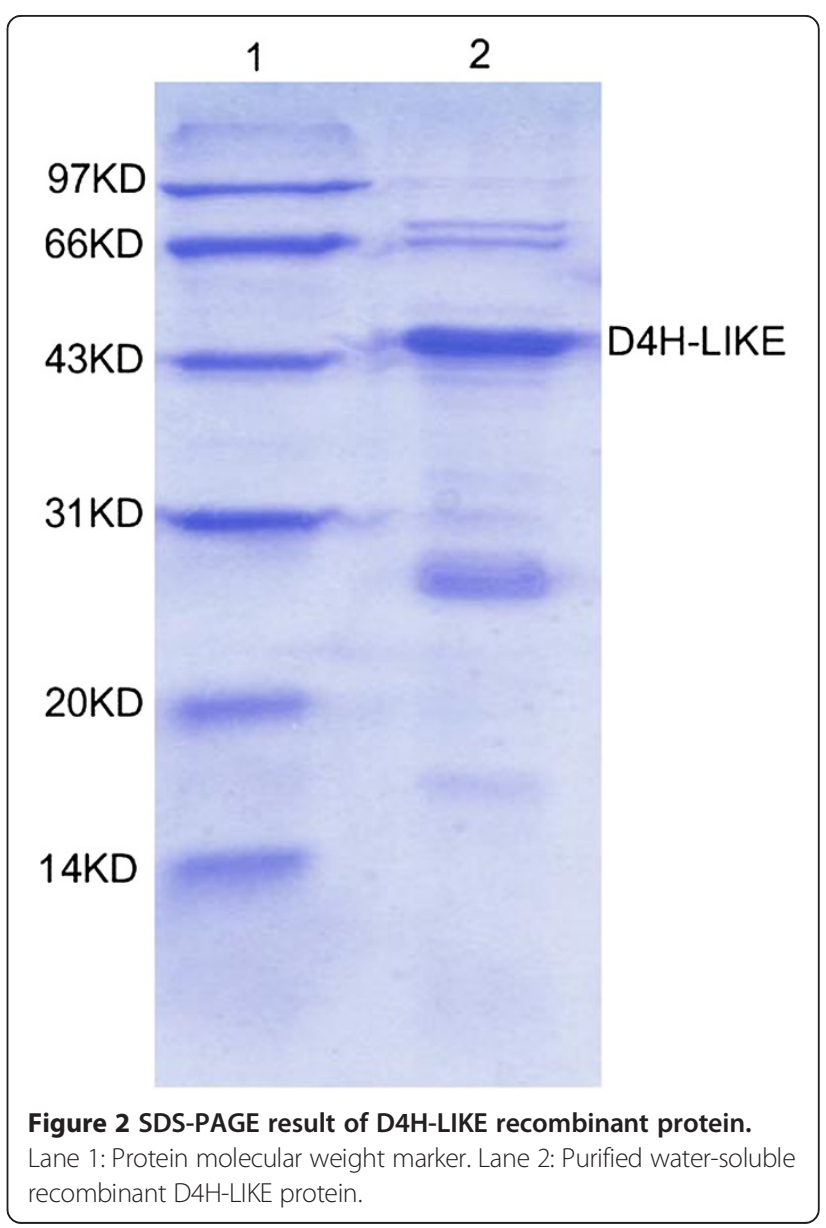




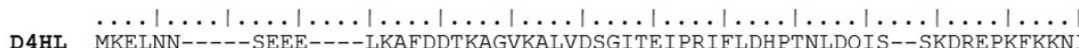
$\begin{array}{ll}\text { D4H } & \text { MKDLNFHAATLSEEESLRELKAFDETKAGVKGIVDTGITKIPRIFIDQPKNLDRIS--VCRGKSDIK--I }\end{array}$ AOH --------MVSSDSVNS------RVETLAGSG--ISTI PKEYIRPKDELVNIGDIFEOEKNNEGPOV $\mathrm{AOH}$ H6H --FS --------MKTAQGVSATLTMEVARVQAIASLSKCMDTI PSEYIRSENEQP-----AATTLHGVVLQV EFE - - - - MGSVS- -

- KANV

80

$\mathrm{D} 4 \mathrm{HL}$

$\ldots|\ldots| \ldots|\ldots| \ldots|\ldots| \ldots|\ldots| \ldots|\ldots| \ldots|\ldots| \ldots|\ldots| \ldots|\ldots| \ldots|\ldots|$ PVIDLDGISTNSE-IRREIVEKIREASEKWGFFQIVNHGI PQEVMDDMIVGIRRFHEQDNEIKKQF--YT PVINLNGLSSNSE-IRREIVEKIGEASEKYGFFQIVNHGI PQDVMDKMVDGVRKFHEQDDQIKRQY--YS PTIDLKEIESDNEKVRAKCREKLKKAAVDWGVMHLVNHGISDELMDKVRKAGKAFFD-LPIEQKEK--YA PIIDLQQ------HHHLLVQQITKACQDFGLFQVINHGF PEELMLETMEVCKE FFALPAEEKEKF--KP PVIDLRDPDEN-----KMVKLIADASKEWGIFQLINHGI PDEAIADLQKVGKEFFEHVPQEEKEL--IA

EFE G200 IPNS PLIDLQNLLSDPS-STLDASRLISEACKKHGFFLVVNHGISEELISDAHEYTSRFFDMPLSEKQRV--LR PKIDVSPLFGDDQAAKMRVAQQIDAASRDTGFFYAVNHGINVQRLSQKTKEFHMSITPEEKWDLAIRAYN

150

160

170

180

190

200

210 $\ldots \ldots|\ldots| \ldots|\ldots| \ldots|\ldots| \ldots|\ldots| \ldots|\ldots| \ldots|\ldots| \ldots|\ldots| \ldots|\ldots|$ D4HL RDRT--KSFRYTSNFVLNPKIA------CNWRDTFECTMAPHQPNPQ---------DLPDICRDIMM D4H RDRFN-KNFLYSSNYVLIPGIA-------CNWRDTMECIMNSNQPDPQ-----------EFPDVCRDILM AOH NDQASGKIQGYGSKLANNASGQ-------LEWEDYFFHCVYPEDKRDLSIW-------PQTPADYIEATA H6H KGEAAKFELPLEQKAKLYVEGEQLSNEEFLYWKDTLAHGCHPLDQDLVNSWP-------EKPAKYREVVA FS KTPGSNDIEGYGTSLQKEVEGK-------KGWVDHLFHKIWPPSAVNYRYW-------PKNPPSYREANE $\begin{array}{ll}\text { FS } & \text { KTPGSNDIEGYGTSLQKEVEGK------KGWVDHLFHKIWP PSAVNYRYW------PKNPPSYREANE } \\ \text { EFE ASKG-------LEAVQAEVTD-------LDWESTFFLRHLPTSNISQVP--------DLDEEYREVMR }\end{array}$ G200 KSGES---VGYASSFTGRFSTK-------LPWKETLSFRFCDDMSRSKSVQDYFCDALGHGFQPFGKVYQ IPNS KEHQDQVRAGYYLSIPGKKAVES------FCYLNPNFTPDHPRIQAKTPTHEVNVWPDETKHPGFQDFAE
220
230
240
250
260
270
280

$\ldots|\ldots| \ldots|\ldots| \ldots|\ldots| \ldots|\ldots| \ldots|\ldots| \ldots|\ldots| \ldots|\ldots| \ldots|\ldots| \ldots \mid$

D4HL KYISYTRNLGLTLFELLSEALGLKSNRLKDMHCDEG---VELVGHYYPACPQPELTLGTSK---....

D4H KYSNYVRNLGLILFELLSEALGLKPNHLEEMDCAEG---LILLGHYYPACPQPELTFGTSK-------

AOH EYAKQLRELATKVLKVLSLGLGLDEGRLEKEVGGLEELLLQMKINYYPKCPQPELALGVEA--------

H6H KYSVEVRKLTMRMLDYICEGLGLKLGYFDNELSQIQ----MMLTNYYPPCPDPSSTLGSGG---------

FS EYGKRMREVVDRIFKSLSLGLGL-EGHEMIEAAGGDEIVYLLKINYYPPCPRPDLALGVVA--------

EFE DFAKRLEKLAEELLDLLCENLGLEKGYLKNAFYGSKGPNFGTKVSNYPPCPKPDLIKGLRA-------

G200 EYCEAMSSLSLKIMELLGLSLGVKRDYFREFFEEND---SIMRLNYYPPCIKPDLTLGTGP-

IPNS QYYWDVFGLSSALLKGYALALGKEENFFARHFKPDDTLASVVLIRYPYLDPYPEAAIKTAADGTKLSFEW $\begin{array}{lllllll}290 & 300 & 310 & 320 & 330 & 340 & 350\end{array}$ $\ldots|\ldots| \ldots|\ldots| \ldots|\ldots| \ldots|\ldots| \ldots|\ldots| \ldots|\ldots| \ldots|\ldots| \ldots|\ldots| \ldots \mid$ HTDT GFLTMLQQD-QIGGLQVLYENHQWVDVPF I PGALI INI GDFLQIISNDDKFKSAPHRVLANKNGPRI SDSGFLTILMQD-QIGGLQILLEN-QWIDVPFIPGALVINIADLLQLITNDKFKSVE DVSALTFILHN-MVPGLQLFYEG-KWVTAKCVPNSIVMHIGDTLEILSNGKYKS I YD GNLITLLQQD-LPGLQQLIVKDATWIAVQPI PTAFVVNLGLTLKVITNEKFEGSI DSYITILVPN-EVQGLQVFKDG-HWYDVKYI PNALIVHIGDQVEILSNGKYKSVY DAGGI ILLFQDDKVSGLQLLKDE-QWIDVPPMRHSIVVNLGDQLEVITNGKYKSVI TDAGGI ILLFQDDKVSGLQLLKDE-QWIDVP PMRHS IVVNLGDQLEVITNGKYKSVMHRVIAQTDGTRM
CDPTSLT ILHQD-HVNGLQVFVEN-QWRS IRPNPKAFVVNIGDTFMALSNDRYKSCLHRAVVNSKSERK VSLITVLYQS-NVQNLQVETAA-GYQDIEADDTGYLINCGSYMAHLTNNYYKAPIHRVKWVN-AERQ
M

360

370

380

390

400

410

420

$\ldots|\ldots| \ldots|\ldots| \ldots|\ldots| \ldots|\ldots| \ldots|\ldots| \ldots|\ldots| \ldots|\ldots| \ldots|\ldots| \ldots \mid$ D4HL STASVF--MPNFLESAEVRLYGPIKELLSEEN---PPIYEQITAKDYVTVQFSRGLDGDSFLSPFMLNKD D4H SVAVAFGIKTQTQEGVSPRLYGPIKELISEEN---PPIYKEVTVKDFITIRFAKRFDDSSSLSPFRLNNAOH SWAVFCE------PPKEKIILKPLPETVSEDE---PAMFPPRTFAEHIOHKLFRKSOEALLPK-----H6H SIATLIG-------PDYSCTIEPAKELLNQDN---PPLYKPYSYSEFADIYLSDKSDYDSGVKPYKINVFS SWPVFLE------PPSEHEVG-PIPKLLSEAN---PPKFKTKKYKDYVYCKLNKLPQ-

EFE SLASFYN------PGNDAVIYPAPSLIEESKQVYPKFVFDDYMKLYAGLKFQPKEPRFEAMKAMEANVE G200 SLAFFLC-------PKKDRVVTPPRELLDSITSRRYPDFTWSMFLEFTQKHYRADMNTLQAFSDWLTKPI IPNS SLPFFVN-------LGYDSVIDPFDPREPNGK----SDREPLSYGDYLQNGLVSLINKNGQT-------

b

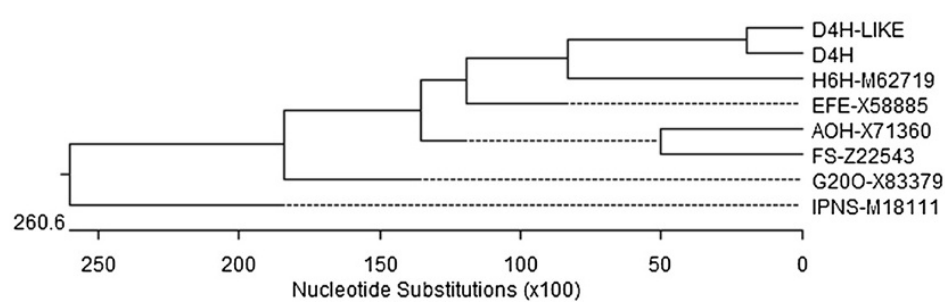

Figure 3 (See legend on next page.) 
(See figure on previous page.)

Figure 3 Relationship of $\boldsymbol{d} \mathbf{4} \boldsymbol{h}$-like with other oxygenase genes. a) Alignment of D4H-like with other dioxygenases. D4H, desacetoxyvindoline-4hydroxylase (GenBank accession number: U71604); AOH, anthocyanidin synthase from Anthirrhinum candida (GenBank accession number: X71360); H6H, hyoscyamine 6-hydroxylase from Hyoscyamus niger (GenBank accession number: M62719); FS, flavonol synthase from Petunia hybrida (GenBank accession number: Z22543); EFE, ethylene forming enzyme from tomato (GenBank accession number: X58885); G200, gibberellin 20-oxidase from Arabidopsis thaliana (GenBank accession number: X83379); IPNS, isopenicillin N-synthase from Aspergillus nidulans (GenBank accession number: M18111). The 19 conserved residues were highlighted in shadow boxes and the binding site for ferrous ions was marked with white characters in black boxes. b) Phylogenetic tree constructed with D4H-like and other 2-oxoglutarate dependent oxygenases using MegAlign software.

of acetosyringone. After cultivation under $28^{\circ} \mathrm{C}$ for another $48 \mathrm{~h}$, cells were collected to do the expression assay. Cells infected with either $A$. tumefaciens containing pCaMV35S: GUS or A. tumefaciens only was used as positive and negative control, respectively. Each assay was performed triplicate.

\section{GUS activity assay}

GUS activity was measured according to Jefferson and Kavanagh (1987). C. roseus transient transgenic cells were homogenized in protein extraction buffer $(0.05 \mathrm{M}$ $\mathrm{NaPO}_{4}$, pH 7.0, 0.1\% SDS, 10 mM EDTA, 20\% methanol, $10 \mathrm{mM} \beta$-ME, Triton X-100) and centrifuged. Supernatant were used to do the assay with fluorometer. Protein concentration was determined using Bradford method (Bio-Rad, USA). GUS enzyme activity was expressed as nanomolar of 4-MU produced per minute per milligram protein.

\section{Results and discussion}

\section{Cloning and characteristics of $d 4 h$-like cDNA and genomic DNA}

A 910 bp of PCR product was obtained applying 5' $5^{\prime}$ RACE method. The full-length cDNA of $d 4$ h-like (Figure 1a) was 1427 bp encoding 372 amino acids with a calculated molecular mass of $42.7 \mathrm{kDa}$ and isolectric point (pI) of 5.31 . The ORF of $d 4 h$-like was fused with the 33 amino acid residues in the pRSET vector at the $\mathrm{N}$-terminal. After induced by IPTG, an approximate 44KD of specific watersoluble protein was expressed in E. coli BL21 (Figure 2), which was right the predicted molecular weight of the recombinant D4H-LIKE protein. The $5^{\prime}$-untranslated region (UTR) was $68 \mathrm{bp}$ and the 3'-UTR was $240 \mathrm{bp}$ including 26 base poly $(\mathrm{A})^{+}$tail. Analysis with tBlastX showed that d4h-like had 66\% (250/378) identities and 80\% (303/378) positives to $d 4 h$ at the amino acid level.

The genomic organization of $d 4 h$-like was similar with $d 4 h$ (Figure 1b). It contained three exons and two introns, 85 and $128 \mathrm{bp}$ in length, being located at the same conserved amino acid consensus sequences as those of $d 4 h$. But either intron of $d 4 h$-like was shorter than the corresponding one of $d 4 h$, which was 205 and $1720 \mathrm{bp}$.

\section{Alignment of D4H-LIKE with the other dioxygenases}

NCBI conserved domain-searching results using Swissprot database indicated that the identity of D4H-LIKE with the other dioxygenases (Figure 3a) ranked from 27\% for IPNS from Aspergillus nidulans (Ramon et al. 1987), 29\% for Hyoscyamine 6-beta-hydroxylase $(\mathrm{H} 6 \mathrm{H})$ from Hyoscyamus niger (Matsuda et al. 1991) and anthocyanidin synthase (AS) from apple (Davis 1993), 33\% for Ethyleneforming enzyme from tomato (Holdsworth et al. 1987) and G20O from Arabidopsis thaliana (Phillips et al. 1995) to $34 \%$ for Flavonol synthase (FS) from Petunia $x$ hybrida (Holton et al. 1993). These enzymes and D4H all belonged to 2OG-Fe(II) oxygenase superfamily including 2-oxoglutarate (2OG) and Fe(II)-dependent oxygenase members. The C-terminal of this superfamily enzymes contained a prolyl 4-hydroxylase alpha subunit and the holoenzyme had the activity of procollagen-proline dioxygenase (EC:1.14.11.2) catalyzing the following reaction: L-proline-[procollagen] + 2-oxoglutarate $+\mathrm{O}(2)=$ trans-4-hydroxy-L- proline-[procollagen] + succinate + CO (2) (Helaakoski et al. 1995). Among the 19 highly conserved residues including $\mathrm{Ala}_{84}, \mathrm{Gly}_{89}, \mathrm{Gly}_{97}, \mathrm{His}_{96}, \mathrm{His}_{235}, \mathrm{His}_{292}$, $\mathrm{Pro}_{226}, \mathrm{Leu}_{197}, \mathrm{Gln}_{253}, \mathrm{Arg}_{293}$, and $\mathrm{Ser}_{304}$, the triad $\mathrm{His}_{235^{-}}$ $\mathrm{X}-\mathrm{Asp}_{237}$, together with $\mathrm{His}_{292}$ (Figure 3a), were proved to be the binding sites for ferrous ions in IPNS (Roach et al. 1995). The equivalent residues, highlighted with white characters in black boxes in Figure 3a, were also conserved in D4H-LIKE and D4H. All the information indicates that D4H-LIKE has the characteristics of oxidase, in particular, the enzymatic characteristics associated with Fe(II)dependent oxygenase just like $\mathrm{D} 4 \mathrm{H}$.

\section{Phylogenetic analysis}

The phylogenetic tree (Figure 3b) established with MegAlign software (DNASTAR Inc., Madison, WI, USA) showed that D4H-LIKE was closely clustered with D4H and kept a little far from EFE, AOH, FS, G20O, and IPNS. This result, taken together with the similar gene structure, implied that D4H-LIKE and D4H were closely related with each other in the genetic evolutionary process and D4H-LIKE may have similar functions in $C$. roseus. 
Isolation and characterization of $d 4 \mathrm{~h}$-like promoter An approximately 2,910 bp promoter region of $d 4 h$-like was isolated. The promoter contained a typical TATA box, present at $-25 \mathrm{bp}$ upstream of the transcriptional start site
(TSS). Analysis with PlantCARE showed that a number of potential cis-acting elements corresponding to regulatory signals existed upstream of the TATA-box in this region (Table 1 and Additional file 1: Figure S1). AT-rich

Table 1 Putative cis-elements in $\mathbf{d 4 h}$-like promoter

\begin{tabular}{|c|c|c|c|c|}
\hline Motif name & Sequence & Position & Motif numbers & Function \\
\hline O2-site & GATGATGTGG & $-2858 /-2849(-)$ & 1 & $\begin{array}{l}\text { Cis-acting regulatory element involved in zein } \\
\text { metabolism regulation }\end{array}$ \\
\hline \multirow[t]{2}{*}{ TC-rich repeats } & \multirow[t]{2}{*}{ GTTTCTTAC } & $-2422 /-2413(+)$ & \multirow[t]{2}{*}{2} & \multirow{2}{*}{$\begin{array}{l}\text { Cis-acting element involved in defense and stres } \\
\text { responsiveness }\end{array}$} \\
\hline & & $-1254 /-1245(+)$ & & \\
\hline \multirow[t]{2}{*}{ Sp1 } & \multirow[t]{2}{*}{$\mathrm{CC}(\mathrm{G} / \mathrm{A}) \mathrm{CCC}$} & $-2463 /-2458(-)$ & \multirow[t]{2}{*}{2} & \multirow[t]{2}{*}{ Light responsive element } \\
\hline & & $-2369 /-2364(+)$ & & \\
\hline \multirow[t]{2}{*}{ HSE } & \multirow[t]{2}{*}{ AAAAAATTTC } & $-2307 /-2298(+)$ & \multirow[t]{2}{*}{2} & \multirow{2}{*}{$\begin{array}{l}\text { Cis-acting element involved in heat stress } \\
\text { responsiveness }\end{array}$} \\
\hline & & $-359 /-350(+)$ & & \\
\hline \multirow[t]{4}{*}{ Box 4} & \multirow[t]{4}{*}{ ATTAAT } & $-2236 /-2231(+)$ & \multirow[t]{4}{*}{4} & \multirow{4}{*}{$\begin{array}{l}\text { Part of a conserved DNA module involved in } \\
\text { light responsiveness }\end{array}$} \\
\hline & & $-1677 /-1672(+)$ & & \\
\hline & & $-800 /-795(+)$ & & \\
\hline & & $-236 /-231(+)$ & & \\
\hline TCCC-motif & ТCTCCCT & $-2253 /-2247(+)$ & 1 & Part of a light responsive element \\
\hline \multirow[t]{3}{*}{ ARE } & \multirow[t]{3}{*}{ TGGTTा } & $-2207 /-2202(+)$ & \multirow[t]{3}{*}{3} & \multirow{3}{*}{$\begin{array}{l}\text { Cis-acting regulatory element essential for the } \\
\text { anaerobic induction }\end{array}$} \\
\hline & & $-2092 /-2087(+)$ & & \\
\hline & & $-186 /-181(-)$ & & \\
\hline \multirow[t]{2}{*}{ TGACG-motif } & \multirow[t]{2}{*}{ TGACG } & $-2167 /-2163(+)$ & \multirow[t]{2}{*}{2} & \multirow{2}{*}{$\begin{array}{l}\text { Cis-acting regulatory element involved in the } \\
\text { MeJA-responsiveness }\end{array}$} \\
\hline & & $-1180 /-1176(+)$ & & \\
\hline \multirow[t]{4}{*}{ Box 1} & \multirow[t]{4}{*}{ TTTCAAA } & $-1980 /-1974(+)$ & \multirow[t]{4}{*}{4} & \multirow[t]{4}{*}{ Light responsive element } \\
\hline & & $-1411 /-1405(+)$ & & \\
\hline & & $-380 /-374(+)$ & & \\
\hline & & $-914 /-908(-)$ & & \\
\hline I-box & AAGATAAGA & $-1965 /-1957(-)$ & 3 & Part of a light responsive element \\
\hline & & $-1140 /-1132(-)$ & & \\
\hline & & $-1085 /-1077(-)$ & & \\
\hline Box II & TGGTAATAA & $-1251 /-1243(-)$ & 1 & Part of a light responsive element \\
\hline ERE & ATTTCAAA & $-1786 /-1779(-)$ & 2 & Ethylene-responsive element \\
\hline & & $-381 /-374(+)$ & & \\
\hline Box III & CATTTACACT & $-1650 /-1642(+)$ & 1 & Protein binding site \\
\hline GA-motif & ATAGATAA & $-1557 /-1550(+)$ & 2 & Part of a light responsive element \\
\hline & & $-671 /-664(+)$ & & \\
\hline AT-rich sequence & TAAAATACT & $-1419 /-1411(+)$ & 1 & $\begin{array}{l}\text { Element for maximal elicitor-mediated } \\
\text { activation (2copies) }\end{array}$ \\
\hline TCT-motif & TCTTAC & $-1338 /-1333(+)$ & 1 & Part of a light responsive element \\
\hline GARE-motif & AAACAGA & $-892 /-886(-)$ & 1 & Gibberellin-responsive element \\
\hline GAG-motif & AGAGAGT & $-286 /-280(-)$ & 1 & Part of a light responsive element \\
\hline G-box & CACATGG & $-227 /-221(-)$ & 1 & $\begin{array}{l}\text { Cis-acting regulatory element involved in } \\
\text { light responsiveness }\end{array}$ \\
\hline circadian & CAANNNNATC & $-156 /-146(+)$ & 1 & $\begin{array}{l}\text { Cis-acting regulatory element involved in } \\
\text { circadian control }\end{array}$ \\
\hline TATA-box & $\operatorname{TATA}(T / A) A(T / A) A$ & $-25 /-18(+)$ & 1 & $\begin{array}{l}\text { Core promoter element around }-30 \text { of } \\
\text { transcription start }\end{array}$ \\
\hline
\end{tabular}


sequence was element for maximal elicitor-mediated activation. HSE was related to heat stress responsiveness. ARE was cis-acting regulatory element essential for the anaerobic induction. TGACG-motif involved in the MeJAresponsiveness. GARE-motif was involved in the gibberellin responsiveness and ERE acted as ethylene-responsive element. The existence of such cis-acting elements in d4h-like promoter indicated that $d 4 h$-like might be controlled by a complicated regulatory mechanism and probably responded to various developmental and environmental signals.

\section{Expression profile of $d 4 h$-like in $C$. roseus plant and the cultured cells}

RT-qPCR analysis revealed the transcripts of $d 4 h$-like was accumulated high in roots and flowers, and very low in stems and leaves (Figure 4a). The expression level of $d 4 \mathrm{~h}$ like in roots was about 100-fold, 530-fold, and 5300-fold higher than that in flowers, stems, and leaves, respectively. Among the three cell lines, $\mathrm{C}_{20}$ hi cells exhibited the highest capacity to accumulate $d 4 h$-like mRNA. Both $\mathrm{C}_{20} \mathrm{D}$ and $\mathrm{C}_{20}$ cells accumulated very little $d 4$ h-like transcripts whose level was about 200-fold and 270-fold lower than that in $\mathrm{C}_{20}$ hi, respectively (Figure $4 \mathrm{a}$ ). This result suggested that d4h-like has root-specific expression characteristics.

\section{Effects of MeJA and 2,4-D on the transcript accumulation of $d 4 h$-like}

After treating with MeJA, the transcription of $d 4 h$-like was gradually increased, reaching the highest level, about 25 -fold high compared with the control at the $36^{\text {th }} \mathrm{hr}$, and then decreased but still at an up-regulated level after 48 and $72 \mathrm{hr}$ (Figure 4b), suggesting that MeJA could induce $d 4 h$-like to express. Since the EST fragment of d4h-like was obtained through screening the SSH cDNA library established using $\mathrm{C}_{20}$ hi and $\mathrm{C}_{20} \mathrm{D}$ cells and the difference between these two cell lines was that $\mathrm{C}_{20}$ hi grew well in B5 media without 2,4-D, we speculate that the high transcription of $d 4 h$-like in $\mathrm{C}_{20}$ hi cells may result from the absence of 2,4-D in the media. To demonstrate this speculation, $2 \mathrm{mg} / \mathrm{L}$ of 2,4-D was added into B5 media culturing $\mathrm{C}_{20}$ hi cells and the transcripts of d4h-like was detected with semi-quantitative RT-PCR, which proved the expression of $d 4 h$-like was obviously inhibited by 2,4-D (Figure 4c).

Taking together with the existence of ethylene-, gibberellin-, MeJA-responsive elements and circadian control regulatory element in the promoter region, we suggest that $d 4 h$-like may be involved in the growth of $\mathrm{C}_{20}$ hi cells.

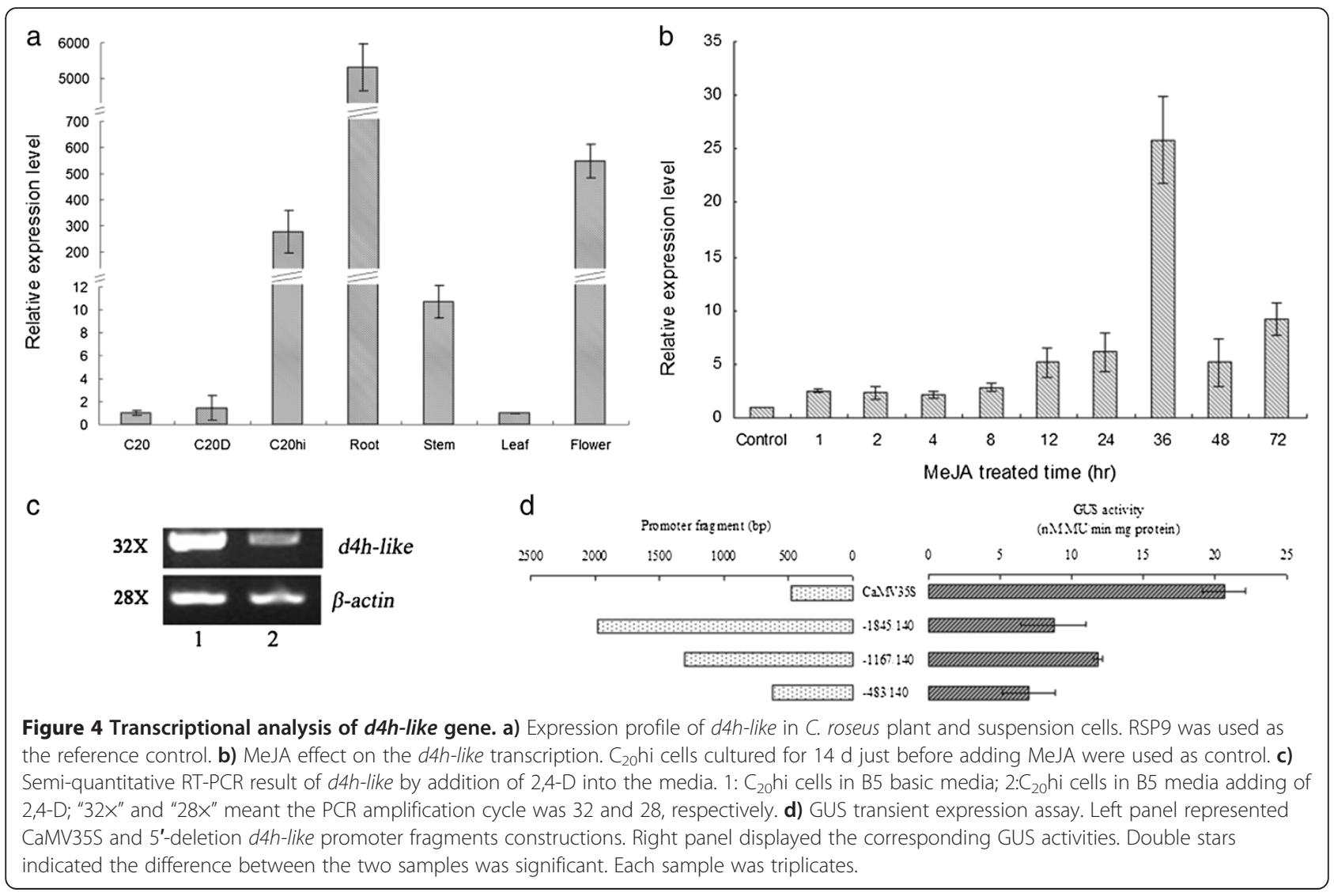




\section{Function analysis of the $d 4 h$-like promoter in C. roseus suspension cells}

Transient expression assay revealed that the activity of d4h-like promoter was $8.77 \pm 2.29 \mathrm{nM} \mathrm{MU} / \mathrm{min} / \mathrm{mg}$ proteins for $-1845 /+140 \mathrm{bp}, 11.85 \pm 0.30 \mathrm{nM} \mathrm{MU} / \mathrm{min} / \mathrm{mg}$ proteins for $-1167 /+140 \mathrm{bp}$, and $7.00 \pm 1.84 \mathrm{nM} \mathrm{MU} /$ $\mathrm{min} / \mathrm{mg}$ proteins for $-483 /+140 \mathrm{bp}$ fragment, and that of the CaMV35S was $20.65 \pm 1.494 \mathrm{nM} \mathrm{MU} / \mathrm{min} / \mathrm{mg}$ proteins (Figure 4d). Analysis with SPSS19.0 revealed that there were no significant difference between the $35 \mathrm{~S}$ promoter and the $-1845 /+140$ bp fragment $(p=$ $0.512>0.05)$, and the $-1167 /+140$ bp fragment $(p=$ $0.316>0.05)$, which indicated that the $-1167 /+140 \mathrm{bp}$ region had the capability to drive GUS to express in transiently transformed C. roseus cells. The $-483 /+140$ bp fragment showed significant difference with the $35 \mathrm{~S}$ promoter $(p=0.020<0.05)$, implying that the cis-acting elements within $-1167 /-483$ bp region may be necessary for the transcription of the gene. All the results suggested that $d 4 h$-like was an active gene in vivo.

\section{Conclusion}

In general, an active $d 4 h$-like gene was cloned from $C$. roseus which showed different transcriptional expression profiles from $d 4 h$. It will be interesting to investigate the roles and the relationship between $d 4 h$-like and the biosynthesis of alkaloids such as vindoline, tryptamine, serpentine, and ajmalicine in C. roseus.

\section{Additional file}

Additional file 1: Table S1. Primers used for PCR. Figure S1. Analysis of d4h-like promoter with PlantCare.

\section{Competing interests}

The authors declare that they have no competing interests.

\section{Authors' contributions}

$C Z$ carried out most of the research, did the data analysis, and drafted the manuscript. JZ helped perfect the results of qRT-PCR, Agrobacterium-mediated transient transformation, and GUS activity assay. SJZ directed the experiments and finished the manuscript. ZBH supervised the whole research. All authors read and approved the final manuscript.

\section{Acknowledgement}

This study was supported by grants from the National Natural Science Foundation of China (No. 30200358) and the Doctorate Specialized Research Fund from China Ministry of Education (20070268008).

Received: 5 March 2014 Accepted: 5 March 2014

Published: 13 March 2014

\section{References}

Davis KM (1993) A Malus CDNA with homology to Anthirrhinum candida and Zea A2 genes. Plant Physiol 103:1015

El-Sayed M, Verpoorte R (2007) Catharanthus terpenoid indole alkaloids: biosynthesis and regulation. Phytochem Rev 6:277-305

Helaakoski T, Annunen P, Vuori K, MacNeil IA, Pihlajaniemi T, Kivirikko K (1995) Cloning, baculovirus expression, and characterization of a second mouse prolyl 4-hydroxylase alpha-subunit isoform: formation of an alpha 2 beta 2 tetramer with the protein disulfide-isomerase/beta subunit. Proc Natl Acad Sci U S A 92:4427-4431

Holdsworth MJ, Bird CR, Ray J, Schuch W, Grierson D (1987) Structure and expression of an ethylene-related mRNA from tomato. Nucl Acid Res 15:731-739

Holton TA, Brugleira F, Tanaka Y (1993) Cloning and expression of flavonol synthase from Petunia hybrida. Plant J 4:1003-1010

Jefferson RA, Kavanagh A (1987) GUS fusions: B-glucuronidase as fusion marker in higher plants. EMBO J 6(13):3901-3907

Matsuda J, Okabe S, Hashimoto T, Yamada Y (1991) Molecular cloning of hyoscyamine 6-hydroxylase, a 2-oxoglutaratedependent dioxygenase from cultured roots of Hyoscyamus niger. J Biol Chem 226:9460-9464

Peebles CAM, Hughes EH, Shanks JV, San KY (2009) Transcriptional response of the terpenoid indole alkaloid pathway to the overexpression of ORCA3 along with jasmonic acid elicitation of Catharanthus roseus hairy roots over time. Metab Eng 11:76-86

Phillips A, Ward DA, Ukness S, Appleford NEJ, Lange T, Huttly AK, Gaskin P, Graebe JE, Hedden P (1995) Isolation and expression of three gibberellin 20-oxidase cDNA clones from Arabidopsis. Plant Physiol 108:1049-1057

Power R, Kurz W, Luca V (1990) Purification and characterization of acetylcoenzyme A: deacetylvindoline 4-O-acetyltransferase from Catharanthus roseus. Arch Biochem Biophys 279:370-376

Ramon D, Carramolino L, Patino C, S'anchez F, Penalva MA (1987) Cloning and characterization of the isopenicillin $\mathrm{N}$ synthase gene mediating for formation of the beta-lactam ring in Aspergillus nidulans. Gene 57:171-181

Roach PL, Clifton IJ, Fülöp V, Harlos K, Barton GJ, Hajdu J, Andersson I, Schofield CJ, Baldwin JE (1995) Crystal structure of isopenicillin N synthase is the first from a new structural family of enzymes. Nature 375:700-704

St-Pierre B, Vazquez-Flota FA, De Luca V (1999) Multicellular compartmentation of Catharanthus roseus alkaloid biosynthesis predicts intercellular translocation of a pathway intermediate. Plant Cell 11:887-900

Vazquez-Flota F, De Carolis E, Alarco AM, De Luca V (1997) Molecular cloning and characterization of desacetoxyvindoline-4-hydroxylase, a 2-oxoglutarate dependent-dioxygenase involved in the biosynthesis of vindoline in Catharanthus roseus (L.) G. Don. Plant Mol Biol 34:935-948

Verpoorte R, Van der Heijden R, Memelink J (2000) Engineering the plant cell factory for secondary metabolite production. Transgenic Res 9:323-343

Wang Q, Yuan F, Pan Q, Li M, Wang G, Zhao J, Tang K (2010) Isolation and functional analysis of the Catharanthus roseus deacetylvindoline-4-O-acetyltransferase gene promoter. Plant Cell Reports 29:185-192

doi:10.1186/1999-3110-55-29

Cite this article as: Zhou et al:: An active Catharanthus roseus desacetoxyvindoline-4-hydroxylase-like gene and its transcriptional regulatory profile. Botanical Studies 2014 55:29.

\section{Submit your manuscript to a SpringerOpen ${ }^{\circ}$ journal and benefit from:}

- Convenient online submission

- Rigorous peer review

- Immediate publication on acceptance

- Open access: articles freely available online

- High visibility within the field

- Retaining the copyright to your article

Submit your next manuscript at $>$ springeropen.com 